\title{
Investigation of Barriers to Access Hepatitis B Testing among Secondary School Students after a Peer Education Study in Jos, Nigeria
}

\author{
Article by Mary Mathew ${ }^{1}$, Sonika Raj ${ }^{2}$, Femi Rufus Tinuola ${ }^{3}$ \\ ${ }^{1}$ Abnira Medical Centre, Nigeria \\ ${ }^{2}$ Texila American University \\ ${ }^{3}$ Adekunle Ajasin University, Ondo state \\ E-mail: matshugs1992@gmail.com ${ }^{1}$, adufem2000@yahoo.com ${ }^{3}$
}

\begin{abstract}
A high average prevalence rate of $11-13.7 \% \%$ for viral hepatitis B exists in Nigeria. This study examined the barriers to access hepatitis $B$ virus $(H B V)$ testing among senior secondary school students in six public day secondary schools located in Jos South Local Government Area, Plateau state. It also related the beliefs held on $H B V$ in relation to barriers for access to HBV testing following the impact of a peer education intervention.

A quasi-experimental study was carried out on six hundred students selected by a multistage sampling technique. A pre-tested formal self-administered questionnaire (SAQ) was used to collect data pre and twelve weeks post intervention. Chi-square and students t-test was done to compare intervention and control groups on outcome variables. Results showed the age distribution of the respondents was 10-24 years with majority of respondents (86.7\%) in the age group 15-19 years. The most frequent reason got as a barrier for accessing HBV test was 'I did not know a HBV test was available'. This was related to the belief that 'parents were keen to agree' for the student to have a hepatitis B test done as shown by the chi-square test performed post intervention between intervention and control group using chi-square test was found. There was no significant difference in the belief by students: I have not done a HBV test. However, the students tested for HBV were only from the intervention group showing access to HBV testing was enhanced by its direct availability in the intervention schools. This is in line with the barrier by students that they did not have availability of $H B V$ test. A prevalence rate of $9.1 \%$ was found on HBV testing among the students.
\end{abstract}

Keywords: Hepatitis B testing, secondary school, student, barrier, access, prevalence.

\section{Introduction}

Nigeria contributes significantly to the burden of chronic viral hepatitis globally. Viral hepatitis is the seventh leading cause of death globally (WHO, 2018). An estimated $95 \%$ of individuals with chronic $\mathrm{HBV}$ or HCV infection, or both, are unaware of their infection and so do not benefit from clinical care, treatment, and interventions that are designed to reduce onward transmission (Spearman et al.,2017). WHO's vision is for "a world where viral hepatitis transmission is halted and everyone living with viral hepatitis has access to safe, affordable and effective prevention, care and treatment services" (WHO, 2018). The strategy also includes targets for the elimination of hepatitis $B$ and $C$ as public health threats - a $90 \%$ reduction in new chronic infections and a $65 \%$ reduction in mortality by 2030 from 2015 levels (WHO,2018). HBV screening by serologic HBV testing for Hepatitis B Surface Antigen (HBsAg) is necessary and is the primary way of detection of chronic HBV infection and in the prevention and control of HBV(WHO,2018). HBV testing is routine in many countries (CDC,2018). However, in Africa percentage of individuals tested for HBV are not impressive as less than $1 \%$ of $\mathrm{HBV}$-infected individuals are diagnosed in sub Saharan Africa (SSA), despite the availability of rapid tests with good diagnostic accuracy (Bequelin, Fatou, Seydi \& Wandele, 2018).

Cultural and social barriers increase burden to HBV infection as seen in Pakistan (Aziz Ali, Suhail \&Ali, 2016). The barriers that hinder access for HBV testing are many and related to patients, providers, and/or the healthcare system (Hu, Pan \& Goodwin, 2011). In a study in Barkina Faso, West Africa, the barriers detected were patients' ability to pay for testing; a formal health system lacking trained personnel, diagnostic infrastructures, and other resources; patients' familial and social networks that discourage access to testing and HBV knowledge and a weak global politics around HBV (GilesVernick et al, 2016).

The study among senior school (SS) students (16-25 years of age) in public day schools contributed towards getting evidence about barriers to access for HBV testing and prevalence of HBV among this 
age group. It was the first study carried out in Jos South Local Government Area, Plateau state, Nigeria to assess barriers for access to HBV testing. Most studies in Jos have focused on clinical research for viral hepatitis.

\section{Methods}

A Quasi-experimental study peer education intervention among SS3 students in Jos public day Senior Secondary Schools, Jos South Local Government Area, Plateau state, Nigeria to assess beliefs about hepatitis B was done in three stages: pre- intervention, intervention, post-intervention stage. Eligibility criteria consisted of inclusion criteria: a student aged between 10-25 years, male or female, living with either one or both parents, and voluntarily participation in the study. Exclusion criteria were students below the age of ten and twenty-six or above, living with someone else apart from parents, and failure to agree voluntarily to participate in the study.

The sample was drawn using a multistage sampling technique. Day Senior Secondary schools in Jos South Local Government Area, Jos constituted the sampling frame. The primary sampling units was Day Senior Secondary schools (3 Day Senior Secondary schools as intervention schools and 3 Day Senior Secondary schools as controls) selected by random sampling. The 'control' schools selected were matched with 'intervention' schools based on same location so that one ensured the respondents in control and intervention schools shared similar characteristics. The secondary sampling units were two streams of Senior Secondary class in the selected 6 secondary schools (as the Day Senior Secondary schools have an average of three streams per Senior Secondary class) while the tertiary sampling units were the individual students in the class, selecting 50 students in each class/stream. The selection of 50 students in each class/stream (two classes/school) for the six schools by simple random sampling method made a total number of 600 respondents.

For comparing two proportions, the sample size formula used was $n=(Z \alpha / 2+Z \beta) 2 *(p 1(1-p 1)+p 2(1-$ $\mathrm{p} 2)) /(\mathrm{p} 1-\mathrm{p} 2) 2$, where $\mathrm{n}$ is the sample size for a proportion, $\mathrm{Z} \alpha / 2$ is the critical value of the Normal distribution at $\alpha / 2$ (for a confidence level of $95 \%, \alpha$ is 0.05 and the critical value is 1.96 ), $Z \beta$ is the critical value of the Normal distribution at $\beta$ (for a power of $80 \%, \beta$ is 0.2 and the critical value is 0.84 ) and $\mathrm{p} 1$ and $\mathrm{p} 2$ are the expected sample proportions of the two groups. For detecting a difference between two proportions, p1 was taken as 0.3 and $\mathrm{p} 2$ as 0.2 (Ikobah et al., 2016). Imputing values,

$$
\begin{aligned}
& \mathrm{n}=(1.96+0.84) 2 *(0.3(1-0.3)+0.2(1-0.2)) /(0.3-0.2) 2 \\
& \mathrm{n}=290.08
\end{aligned}
$$

Considering a probable non-response of $3 \%$ with $n=300$ for each proportion, the sample size amounted to a total of 600.Research study was done in three stages: pre- intervention, intervention, post-intervention stage.

Pre- intervention- This was done by the administration of formal self-administered questionnaire (SAQ) containing open and close- ended questions, both before and after the peer education intervention to both interventions and controls Day Senior Secondary schools though the peer education intervention was only conducted in the three 'intervention' Day Senior Secondary schools. The questionnaires administered before the peer education intervention served as the baseline assessment of beliefs.

Intervention- Fifteen students (5 per intervention school for 3 schools) were selected as 'Peer Educators' (PEs) using the following criteria: student in the select Day Senior Secondary School aged between 10-25 years, good character, recommended by the school authority as being intelligent, good oral communication skills, active listening skills and able to keep confidentiality. A supervisor of the PEs, preferably a class or subject teacher was also chosen for each school. Both the PEs and teacher supervisor were trained by me with the aim of giving them knowledge on hepatitis and increasing their skills for effective communication and behavior change.

A single peer education intervention of thirty minutes was conducted in each 'intervention' school a week after the baseline assessment by the trained PEs consisting of knowledge on basic facts of hepatitis $\mathrm{B}$ including mode of transmission, prevention and control measures for hepatitis B and its association with Human Immunodeficiency Virus/ Acquired Immunodeficiency Syndrome and hepatitis C. Oneon-one peer sessions were also held on student request during break time.

Post- Intervention- Post intervention data was collected twelve weeks later in all schools (intervention and control). Free voluntary hepatitis B tests was offered to those students who want to undertake the hepatitis B surface antigen blood test in intervention schools.

Blood samples were obtained by registered laboratory scientists for qualitative detection of $\mathrm{HBs} A g$ using rapid chromatographic immunoassays with test kits from ABON (China) having sensitivity, 
specificity and accuracy of $>99 \%, 97 \%$ and $98.5 \%$ respectively. Universal precautions and standard protocols for hepatitis B testing were adhered to.

Data analysis was done in stages. The collected data questionnaires were 'cleaned'. Data was then entered into the computer using Microsoft excel, which was then exported for analysis with the aid of the Statistical Package for Social Sciences (SPSS) 22.0 computer statistical software. Exploratory analysis to check for missing fields was then done. Descriptive statistics summarizing numerical data of age, categorical data of sex and tribe was displayed by frequency tables and graphical representation of observations. This was followed by data analysis done keeping the study objectives and hypothesis in mind. Statistical tests such as students t-test and chi-squared was done to compare intervention and control groups on outcome variables. Results of chi-square values obtained from the study were considered significant at $\mathrm{p} \leq 0.05$.

Ethical approval process involved written approval from the Plateau state government, Local Government, parents/ respondents and the ethical committee (state government approved). Participants were asked to give written consent at the beginning of the questionnaire regarding acceptance of voluntary responses and informed written consent got to do the hepatitis B test. For students below the age of 18 years, informed consent for hepatitis B testing was obtained from the student's parents.

\section{Results}

Six hundred respondents were involved in the study of which 241 were males, 355 were females and 4 non-responses. 300 respondents each in control and intervention study participated. Significant findings were found twelve weeks post intervention at end of study.

Table 1. Distribution of study participants according to age at baseline and end of study

\begin{tabular}{lllllll}
\hline Age & Baseline & & TOTAL & End & & TOTAL \\
\hline & Control & Intervention & & Control & Intervention & \\
\hline $\mathbf{1 0 - 1 4}$ & $25(8.4)$ & $17(5.9)$ & $42(7.2)$ & $25(8.4)$ & $23(7.8)$ & $48(8.1)$ \\
$\mathbf{1 5 - 1 9}$ & $258(86.6)$ & $265(91.7)$ & $523(89.1)$ & $258(86.6)$ & $256(86.8)$ & $514(86.7)$ \\
$\mathbf{2 0}$ & $15(5.0)$ & $7(2.4)$ & $22(3.7)$ & $15(5.0)$ & $16(5.4)$ & $31(5.2)$ \\
\hline TOTAL & $298(100.0)$ & $289(100.0)$ & $587(100.0)$ & $298(100.0)$ & $295(100.0)$ & $593(100.0)$ \\
\hline
\end{tabular}

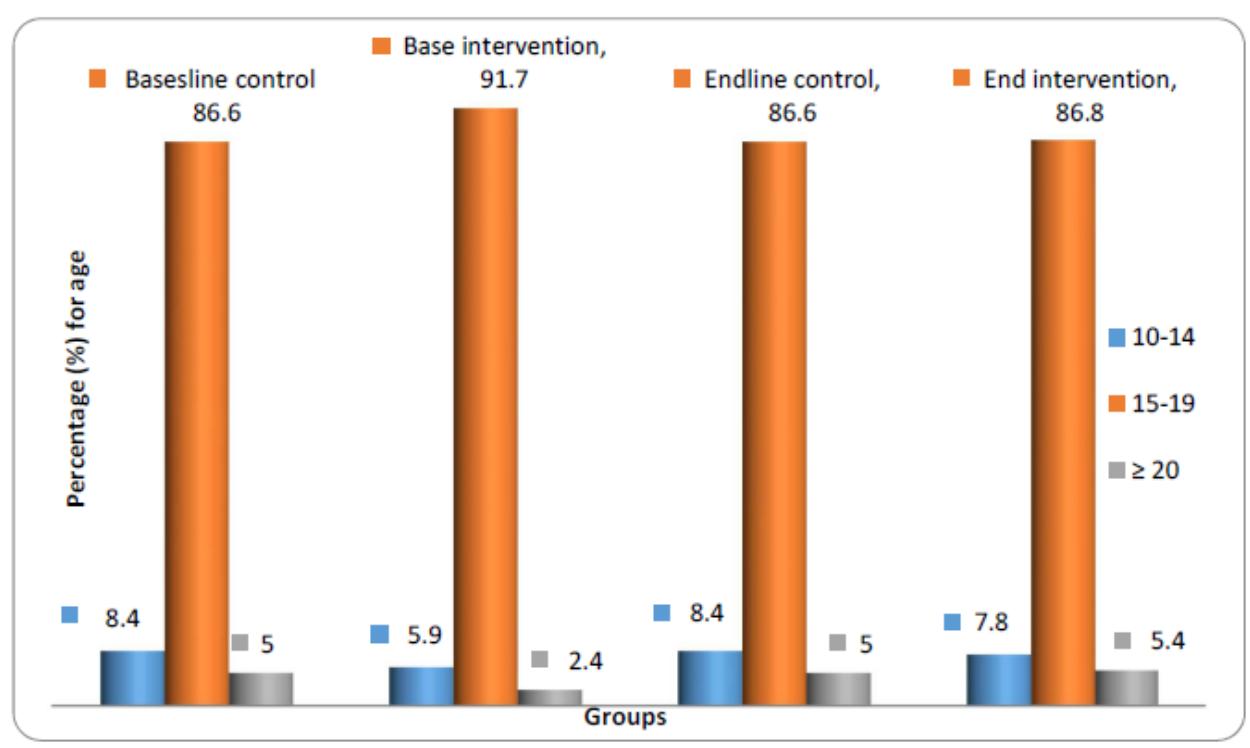

Figure 1. Bar chart showing age distribution between control and intervention groups before and after a peer education intervention on hepatitis B

Table 2. Distribution of study participants according to sex and ethnicity at baseline and end of study

\begin{tabular}{lllllll}
\hline & Baseline & & TOTAL & End & TOTAL \\
\hline Sex & Control & Intervention & & Control & Intervention & \\
\hline Male & $145(48.5)$ & $123(41.4)$ & $268(45.0)$ & $145(48.5)$ & $96(32.3)$ & $241(40.4)$ \\
Female & $154(51.5)$ & $174(58.6)$ & $328(55.5)$ & $154(51.5)$ & $201(67.7)$ & $355(59.6)$ \\
TOTAL & 299(100.0) & 297(100.0) & $596(100.0)$ & $299(100.0)$ & $297(100.0)$ & $596(100.0)$ \\
Ethnicity & Control & Intervention & & Control & Intervention & \\
\hline
\end{tabular}


DOI: $10.21522 /$ TIJPH.2013.06.03.Art020

ISSN: $2520-3134$

\begin{tabular}{lllllll}
\hline Hausa & $31(10.5)$ & $50(17.4)$ & $81(13.9)$ & $31(10.5)$ & $45(16.9)$ & $76(13.7)$ \\
Igbo & $23(7.8)$ & $33(11.5)$ & $56(9.6)$ & $23(7.8)$ & $13(4.9)$ & $36(6.3)$ \\
Yoruba & $11(3.7)$ & $12(4.2)$ & $23(3.9)$ & $11(3.7)$ & $15(5.6)$ & $26(4.7)$ \\
Others & $231(78.0)$ & $192(66.9)$ & $423(72.6)$ & $231(78.0)$ & $193(72.6)$ & $424(75.3)$ \\
TOTAL & $296(100.0)$ & $287(100.0)$ & $583(100.0)$ & $296(100.0)$ & $266(100.0)$ & $596(100.0)$ \\
\hline
\end{tabular}

Table 3. Distribution of respondents according to religion and parents at baseline and end of study

\begin{tabular}{lllllll}
\hline & Baseline & & TOTAL & End & TOTAL \\
\hline Religion & Control & Intervention & & Control & Intervention & \\
\hline Christianit & $285(96.9)$ & $257(88.9)$ & $542(93.0)$ & $286(97.3)$ & $253(91.0)$ & $539(94.2)$ \\
$\mathbf{y}$ & & & & & & \\
Islam & $7(2.4)$ & $32(11.1)$ & $39(6.7)$ & $8(2.7)$ & $25(9.0)$ & $33(5.8)$ \\
Others & $2(0.7)$ & $0(0.0)$ & $2(0.3)$ & $0(0.0)$ & $0(0.0)$ & $0(0.0)$ \\
TOTAL & $294(100.0)$ & $289(100.0)$ & $583(100.0)$ & $294(100.0)$ & $278(100.0)$ & $572(100.0)$ \\
\hline Currently & & & & & & \\
living with & & & & & & \\
parents & & & & & & \\
\hline Yes & $208(72.5)$ & $185(65.8)$ & $393(69.2)$ & $208(72.5)$ & $198(71.0)$ & $406(71.8)$ \\
No & $79(27.5)$ & $96(34.2)$ & $175(30.8)$ & $79(27.5)$ & $81(29.0)$ & $160(28.2)$ \\
TOTAL & $287(100.0)$ & $281(100.0)$ & $568(100.0)$ & $287(100.0)$ & $279(100.0)$ & $566(100.0)$ \\
\hline
\end{tabular}

Table 4. Distribution of respondents according to 'Source of Information' at baseline and end of study

\begin{tabular}{|c|c|c|c|c|c|c|c|c|}
\hline & Baseline & & & & End & & & \\
\hline Source & Control & Intervention & $\chi^{2}$ & $\begin{array}{l}P \\
\text { value }\end{array}$ & Control & $\begin{array}{l}\text { Interventio } \\
\mathrm{n}\end{array}$ & $\chi^{2}$ & $P$ value \\
\hline $\begin{array}{l}\text { Parents } \\
\text { Yes } \\
\text { No }\end{array}$ & $\begin{array}{l}90(32.0) \\
191(68.0)\end{array}$ & $\begin{array}{l}93(39.4) \\
143(60.6)\end{array}$ & 3.054 & 0.081 & $\begin{array}{l}90(32.6) \\
186(67.4)\end{array}$ & $\begin{array}{l}98(36.0) \\
174(64.0)\end{array}$ & 0.711 & 0.399 \\
\hline $\begin{array}{l}\text { Friends } \\
\text { Yes } \\
\text { No } \\
\text { Media }\end{array}$ & $\begin{array}{l}35(12.5) \\
246(87.5)\end{array}$ & $\begin{array}{l}33(14.0) \\
203(86.0)\end{array}$ & 0.262 & 0.609 & $\begin{array}{l}40(14.5) \\
236(85.5)\end{array}$ & $\begin{array}{l}42(15.4) \\
230(84.6)\end{array}$ & 0.097 & 0.756 \\
\hline $\begin{array}{l}\text { Yes } \\
\text { No } \\
\text { Teacher }\end{array}$ & $\begin{array}{l}137(48.8) \\
144(51.2)\end{array}$ & $\begin{array}{l}86(36.4) \\
150(63.6)\end{array}$ & 7.929 & 0.005 & $\begin{array}{l}137(49.6) \\
139(50.4)\end{array}$ & $\begin{array}{l}128(47.1) \\
144(52.9)\end{array}$ & 0.365 & 0.546 \\
\hline $\begin{array}{l}\text { Yes } \\
\text { No } \\
\text { Readin } \\
\text { g books }\end{array}$ & $\begin{array}{l}50(17.8) \\
231(82.2)\end{array}$ & $\begin{array}{l}67(28.4) \\
169(71.6)\end{array}$ & 8.226 & 0.004 & $\begin{array}{l}52(18.8) \\
224(81.2)\end{array}$ & $\begin{array}{l}105(38.6) \\
167(61.4)\end{array}$ & 26.173 & 0.001 \\
\hline $\begin{array}{l}\text { Yes } \\
\text { No }\end{array}$ & $\begin{array}{l}29(10.3) \\
252(89.7)\end{array}$ & $\begin{array}{l}32(13.6) \\
204(86.4)\end{array}$ & 1.293 & 0.255 & $\begin{array}{l}32(11.6) \\
243(88.4)\end{array}$ & $\begin{array}{l}54(19.9) \\
218(80.1)\end{array}$ & 6.967 & 0.008 \\
\hline
\end{tabular}

Table 5. Distribution of participants on barriers (post intervention) regarding access to hepatitis B test

\begin{tabular}{llllll}
\hline Barrier & Control & Intervention & Total & $\chi^{2}$ & P-value \\
\hline I did not know a test for & $113(55.9)$ & $122(62.9)$ & $235(59.3)$ & 8.337 & 0.214 \\
$\begin{array}{l}\text { Hepatitis B was available } \\
\text { Too expensive }\end{array}$ & $10(5.0)$ & $16(8.2)$ & $26(6.6)$ & & \\
$\begin{array}{l}\text { I do not know where to } \\
\text { get test done }\end{array}$ & $54(26.7)$ & $37(19.1)$ & $91(23.0)$ & & \\
$\begin{array}{l}\text { My parents will not allow } \\
\text { me have a test done }\end{array}$ & $23(11.4)$ & $16(8.2)$ & $39(9.8)$ & & \\
$\begin{array}{l}\text { Test done too far away } \\
\text { It is painful/ I am scared }\end{array}$ & $1(0.5)$ & $0(0.0)$ & $1(0.5)$ & $1(0.3)$ & \\
$\begin{array}{l}\text { of injection } \\
\text { Other reasons }\end{array}$ & $1(0.5)$ & $2(1.0)$ & $3(0.8)$ & & \\
\hline
\end{tabular}




\begin{tabular}{llll}
\hline Total 202(100.0) & $194(100.0)$ & $396(100.0)$
\end{tabular}

Table 6. Distribution of respondents on beliefs (post -intervention) regarding personal risk perception of hepatitis B among group of senior secondary students in Jos Nigeria

\begin{tabular}{|c|c|c|c|c|c|}
\hline Beliefs & Control & Intervention & Total & $\chi^{2}$ & P-value \\
\hline \multicolumn{6}{|c|}{ Have you had vaccination against Hepatitis B? } \\
\hline Yes & $95(33.8)$ & $86(29.8)$ & 181(31.8) & \multirow[t]{3}{*}{1.078} & \multirow[t]{3}{*}{0.299} \\
\hline No & $186(66.2)$ & $203(70.2)$ & $389(68.2)$ & & \\
\hline Total & $281(100.0)$ & $289(100.0)$ & $570(100.0)$ & & \\
\hline \multicolumn{6}{|c|}{ Have you done a Hepatitis B test? } \\
\hline Yes & $68(23.5)$ & $51(17.6)$ & $119(20.6)$ & \multirow[t]{3}{*}{3.058} & \multirow[t]{3}{*}{0.080} \\
\hline No & $221(76.5)$ & $238(82.4)$ & $459(79.4)$ & & \\
\hline Total & $289(100.0)$ & $289(100.0)$ & $578(100.0)$ & & \\
\hline \multicolumn{6}{|c|}{ Do you think your parents will agree to you having Hepatitis test? } \\
\hline Yes & $219(80.2)$ & $245(86.9)$ & $464(83.6)$ & \multirow[t]{3}{*}{4.488} & \multirow[t]{3}{*}{0.001} \\
\hline No & $54(19.8)$ & $37(13.1)$ & $91(16.4)$ & & \\
\hline Total & $273(100.0)$ & $282(100.0)$ & $555(100.0)$ & & \\
\hline
\end{tabular}

Table 7. Distribution of participants on hepatitis B test results

\begin{tabular}{llll}
\hline Name of school & HBV Result Negative & HBV Result Positive & Total \\
\hline GSS Giring & $29(29.0)$ & $3(30.0)$ & $32(29.1)$ \\
GSS Anglo Jos & $42(42.0)$ & $6(60.0)$ & $48(43.6)$ \\
GSS Hei-Rayfield & $29(29.0)$ & $1(10.0)$ & $30(27.3)$ \\
Total & $100(100.0)$ & $10(100.0)$ & $110(100.0)$ \\
\hline
\end{tabular}

Table 8. Social characteristics of participants that tested HBV positive

\begin{tabular}{lll}
\hline Social characteristics & Frequency & Percentage \\
\hline Age group & & \\
$\mathbf{1 0 - 1 4}$ & 0 & 0.0 \\
$\mathbf{1 5 - 1 9}$ & 10 & 100.0 \\
$\geq \mathbf{2 0}$ & 0 & 0.0 \\
Sex & & \\
Male & 2 & 20.0 \\
Female & 8 & 80.0 \\
\hline
\end{tabular}

Table 9. Testing null hypothesis accessing hepatitis B test among students assigned to the intervention and control groups

\begin{tabular}{|l|l|l|l|l|l|}
\hline Variables & Control & Intervention & Total & $\chi 2$ & P-value \\
\hline \multicolumn{2}{|l|}{} & & & & \\
\hline Total \# participants & 299 & 297 & $596(100)$ & 95.7 & 0.001 \\
\hline $\begin{array}{l}\text { \# that did the HBV } \\
\text { test }\end{array}$ & $0(0)$ & $110(37.0)$ & $110(37.0)$ & & \\
\hline
\end{tabular}

\section{Discussion}

The age distribution of the respondents was 10-24 years with a mean age of $16.65 \pm 1.72 \mathrm{yrs}$. Age in both groups, control and intervention showed similar age characteristics (Table 1). Majority of respondents $(86.7 \%)$ were in the age group 15-19 years (Figure 1). With infection common among 2040 years $(\mathrm{FMOH}, 2013)$, this is the best age to focus on to prevent HBV by increasing knowledge and awareness to HBV and changing beliefs/ attitudes and cultural norms that facilitate transmission of the disease. More so, as awareness and risk perception on HBV infection are high in Jos among tertiary education institution students (University of Jos), but uptake of HB vaccine low and findings worst for non-health students (Chingle et al., 2017). Table 2 shows that female participants were more than males at both baseline and at end. The table also shows that majority of respondents were from other tribes (7.5.3\%) with respect to ethnicity, mainly locally based and indigenes of Plateau state. This indicates that findings from the study truly reflects the socio- economic norms of the people of the state. Majority 
of respondents were Christians staying with their parents (Table 3). Interventions targeting parents also needs to be recommended and included in strategizing to prevent disease transmission.

Majority of respondents had heard of HBV (both control and intervention groups), commonly from 'media' which includes the internet. Parents as a group came second as source of information on HBV. Interestingly, as a side finding (Table 4), the study found teachers as a source of information was low before the intervention but significantly increased after the intervention. This means teachers in school need to have an intervention so that their knowledge, awareness improved and subsequently play an important role in addressing barriers for access to HBV testing.

The most important barrier for access to testing for HBV was 'I did not know a HBV test was available' (Table 5). This was followed by 'I do not know where to get the test done' and then, 'My parents will not allow me have a test done'. The last two reasons were not significant. Moreover, in table 6, the belief that 'parents were keen to agree' for the student to have a hepatitis B test done as shown by the chi-square test performed post intervention between intervention and control group. A significant relationship found between control and intervention groups after the peer education intervention, $\chi^{2}=4.48, p=0.001$. Majority of participants had not done a hepatitis test (Table 6).

A HBV prevalence of $9.1 \%$ was found (Table 7). This value is close to the national prevalence of $11 \%$ for viral hepatitis B (National AIDS/STIs Control Program, 2016). The hepatitis B tested positive individuals were all in the 15-19-year age group (Table 8). Other HB viral screening tests to detect Anti$\mathrm{HBc}$, Anti-HBs, IgM anti-HBc need to be done for the HBV positive individuals in order to determine next line of action and treatment (National AIDS/STIs Control Program, 2016). Students tested for HBV were only from the intervention group showing access to HBV testing was enhanced by its direct availability in the intervention schools (Table 9). This is in line with the barrier by students that they did not have availability of HBV test.

For a successful peer education country program on HBV prevention interventions for youth/ adolescents, more research needs to be done in different parts of the country to get more substantial evidence regarding the barriers for different age groups and different socio-cultural contexts.

\section{Conclusion}

The study revealed that despite short follow up period, the effects of a peer education intervention in schools are numerous: parents are keen to have students do the HBV test though they did not where it is available.

Implementing secondary school targeted peer education interventions for disease prevention and control of HBV among school youth by allocating appropriate amounts of resources (money, man power, materials and time) by the government authorities is essential. Secondary school teachers and heads of schools need to encourage school based HBV testing either by linking students to where the test is done or getting the test done in schools, increasing awareness on the importance of HBV testing, and linking HBV positive students for further screening and treatment. HBV negative students need to encouraged to go for HBV vaccination. State government needs to ensure resources are available to schools for HBV testing

\section{References}

[1].Aziz Ali, S., Suhail, N., \& Ali, A. S. (2016). Cultural and Social Barriers in increased burden of hepatitis B in Pakistan: Literature review. Journal of Infectious Diseases and Diagnosis, 1(2), 105. Retrieved from https://www.omicsonline.org/open-access/role-of-cultural-and-social-barriers-in-increased-burden-of-hepatitisb-inpakistan-literature-review-jidd-100105.php?aid=75328.

[2].Bequelin, C., Fatou, F., Seydi, M., \& Wandele, G. (2018). The current situation and challenges of screening for and treating hepatitis B in sub-Saharan Africa. Expert review of gastroenterology \& Hepatology, 12(6). Retrieved from https://www.ncbi.nlm.nih.gov/pmc/articles/PMC5154452/.

[3].Center for Disease Control and Prevention. (2018). Hepatitis B: Testing and vaccination. Retrieved from http://www.immunize.org/catg.d/p2110.pdf.

[4].Chingle, M. P., Osagie, I.A., Adams, H., Gwomson, D., Emeribe, N., \& Zoakah, A.I. (2017). Risk perception of hepatitis B infection and uptake of hepatitis B vaccine among students of tertiary institution in Jos. Annals of African Medicine, 16(2), 59-64. Retrieved from http://www.annalsafrmed.org/article.asp?issn=15963519 ; year $=2017$; volume $=16$; issue $=2$; spage $=59$; epage $=64$; aulast $=$ Chingle .

[5].Federal Ministry of Health (2013). National Training Manual on Peer-to-Peer Youth health education. Growing girls and women in Nigeria (G-Win Project). 1-142. Retrieved from http://www.health.gov.ng/doc/TrgManualP2PYHE.pdf. 
[6].Giles-Vernick, T., Hejoaka, F., Sanou, A., Shimakawa, Y., Bamba, I., \& Traore, A. (2016). Barriers to linkage to care for hepatitis B virus infection: a qualitative analysis in burkina faso, west Africa. American Journal of $\begin{array}{lllll}\text { Tropical Medicine } \quad \text { Hygiene, } & \text { 95(6). } & \text { Retrieved }\end{array}$ https://www.ncbi.nlm.nih.gov/pmc/articles/PMC5154452/.

[7].Hu, K. Q., Pan, C. Q., \& Goodwin, D. (2011). Barriers to screening for hepatitis B virus infection in Asian Americans. Digestive Diseases and Sciences, 56(11), 3163-71. Retrieved from https://www.ncbi.nlm.nih.gov/pubmed/21861105.

[8].Ikobah, J., Okpara, H., Elemi, I., Ogarepe, Y., Udoh, E., \& Ekanem, E. (2016). The prevalence of hepatitis B virus infection in Nigerian children prior to vaccine introduction into the National Programme on Immunization schedule. Pan African Medical Journal, 23 (128). doi: 10.11604/pamj.2016.23.128.8756. Retrieved from https://www.ncbi.nlm.nih.gov/pmc/articles/PMC4885699/.

[9].National AIDS/STIs Control Program (2016). Introduction. Guidelines for the Prevention, Treatment and Care of Viral Hepatitis in Nigeria. Federal Ministry of Health. p 1-30.

[10]. Spearman, C.W., Afihene, M., Ally, R., Apica, B., Awuku, Y., Cunha, L., Dusheiko, G., Gogela, N., Kassianides, C., Kew, M., Lam, P., Lesi, O., Lohoues-Kouacou, M., Mbaye, S., Musabeyezu, E., Musau, B., Ojo, O., Rwegasha, J., Scholz, B., Shewaye,. A.B., Tzeuton, C., Sonderup, M.W. (2017). Hepatitis B in sub-Saharan Africa: strategies to achieve the 2030 elimination targets. The Lancet Gastroenterology \& Hepatology, 2(12), 900909. doi: https://doi.org/10.1016/S2468-1253(17)30295-9.

[11]. Umego, C. F., Mboto, C. I., Mbim, E. N., Edet, U. O., George, U. E., Tarh, J.E. (2018). Epidemiology of hepatitis B virus infection in South South Nigeria: A review. Retrieved from https://www.researchgate.net/publication/323044245_Epidemiology_of_Hepatitis_B_Virus_Infection_in_ South-South_Nigeria_A_Review.

[12]. World Health Organization (2018). Global Health Sector Strategy on Viral Hepatitis 2016-2021: Towards Ending Viral Hepatitis 2016. Retrieved from http://www.who.int/hepatitis/strategy2016-2021/ghss-hep/en/ ID: 101666147. 